УДК 377.015.31:378.663-057.87

Надія Шелест, здобувач кафедри педагогіки Національного університету біоресурсів і природокористування України, м. Київ

\title{
ВИВЧЕННЯ СТАНУ СФОРМОВАНОСТІ ЦІННІСНОГО СТАВЛЕННЯ ДО СТВОРЕННЯ СІМ'Ї У СТУДЕНТІВ АГРАРНИХ КОЛЕДЖІВ
}

У статті проаналізовано стан сформованості иіннісного ставлення до створення сім'ї у студентів аграрних коледжів. Охарактеризовано критерії та відповідні показники сформованості иіннісного ставлення до створення сім'ї у студентів аграрних коледжів: когнітивний (знання щэодо сутності та функцій сім'ї; усвідомлення цінності сім'ї для окремої особистості та суспільства в цілому; усвідомлення важливості моральних иінностей (любові, дружби, вірності, взаємоповаги, взаєморозуміння) як основи сім'ї); емоційно-иіннісний (мотивація на створення сім'ї та виконання подружсніх $і$ батьківських обов'язків; здатність до емпатії; прагнення створювати сімейні відносини і розвивати їх на основі моральних иінностей (любові, дружби, вірності, взаємоповаги, взаєморозуміння); поведінково-діяльнісний (здатністість до адекватного вибору поведінки в різних життєвих ситуаціях; наявність вміння спілкуватися з представниками протилежної статі; здатність до самовдосконалення себе як майбутнього сім'янина).

Ключові слова: иіннісне ставлення до створення сім'ї, критерії і показники, рівні сформованості иіннісного ставлення до створення сім'ї, студенти аграрних коледжів, позааудиторна діяльність.

Jim. 5.

Nadiya Shelest, Applicant of the Pedagogy Department National University of Life and Environmental Sciences of Ukraine, Kyiv

\section{THE STUDY OF THE LEVELS OFTHE FORMATION OF VALUE ATTITUDE TO THE CREATING OF FAMILY AMONG THE STUDENTS OF AGRICULTURAL COLLEGES}

The article analyzes the levels of the formation of value attitude to the creating of family among students of agricultural colleges. The author has described the criteria and correspondent indicators of the levels of the formation of value attitude to the creating of family among students of agricultural colleges. They are the following 1) a cognitive one that is a) knowledge about what family is and how it functions; b) the awareness of family as a value for one person and society on the whole and c) the awareness of the importance of moral values such as love, friendship, faithfulness, mutual respect, mutual understanding as the fundamentals of a family; 2) affective and value one that is a) a motivation to create a family and fulfilling the family and parental functions; b) empathy as one's capacity and c) the desire to create the family relationships and develop them on the basis of moral values such as love, friendship, faithfulness, mutual respect, mutual understanding; 3) behavioral and operational that is a) the ability to make a reasonable choice of one's behavior in different life situations, b) the ability to communicate with representatives of an opposite sex and c) the ability to improve oneself as a future family member.

Taking into account the results of testing of students by using these criteria and indicators we have identified three levels of the formation of value attitude to the creating of family among students of agricultural colleges. These levels are the follows: high, intermediate and low.

The analysis of a summative phase of the experiment presents the necessity to find the theoretical evidence and to test experimentally the feasibility of pedagogical conditions of the formation of value attitude to the creating of family among students of agricultural colleges during the after class activities.

Keywords: value attitude to the creating of family, criteria and indicators, the levels of the formation of value attitude to the creating of family, the students of agricultural colleges, the after class activity.

П остановка проблеми. Серед пріоритетних напрямів педагогічної науки вагоме місце посідає проблема формування ціннісного ставлення до створення сім'ї у студентської молоді, оскільки інституг сім'ї переживає суттєві складнощі: руйнуються сім'ї, спостерігається поширення консенсуальних шлюбів, знижуються виховні функції сім'ї.

У державних документах - Конституції України, Сімейному кодексі України, Законах України "Про освіту”, “Про вищу освіту”,
Національній доктрині розвитку освіти України в XXI столітті, Національній стратегії розвитку України на період до 2012 року; рекомендаціях парламентських слухань на тему: “Інститут сім'ї в Україні: стан, проблеми та шляхи їх вирішення”, Концепції сімейного виховання в системі освіти України “Щаслива родина" на 2012 - 2014 роки - пріоритетним напрямом визначено впровадження програм підготовки студентської молоді до подружнього життя та формування відповідального батьківства, а відтак і 


\section{ВИВЧЕННЯ СТАНУ СФОРМОВАНОСТІ ЦІННІСНОГО СТАВЛЕННЯ}

ДО СТВОРЕННЯ СІМ' Ї У СТУДЕНТІВ АГРАРНИХ КОЛЕДЖІВ

формування ціннісного ставлення до створення сім’і у студентів.

Аналіз останніх досліджень і публікацій. Проблеми підготовки студентської молоді до сімейного життя знайшли відображення у працях вчених-педагогів Т. Алексєєнко, А. Барбінової, Т. Говорун, Л. Канішевської, А. Карасевич, О. Кікінеджі, В. Кравця, Т. Кравченко, Л. Маценко, Л. Повалій, В. Постового, П. Терязі, Л. Яцеленко та інших.

Різні аспекти виховання студентів аграрних навчальних закладів розглядаються упрацях I. Данченко, О. Зубчевської, П. Лузана, С. Ніколаєнка, О. Осаульчик, Р. Сопівника, І. Сопівник, Л. Фенчак, В. Шинкарука та інших.

Водночас поза увагою дослідників залишився такий аспект, як вивчення стану сформованості ціннісного ставлення до створення сім’ї у студентів аграрних коледжів.

Мета статті - проаналізувати стан сформованості ціннісного ставлення до створення сім'ї у студентів аграрних коледжів.

Виклад основного матеріалу дослідження. Ціннісне ставлення до створення сім'ї інтегрована моральна якість особистості, яка являє собою єдність мотивів, переконань, свідомості, емоційної та діяльнісної сфери. Ознаками сформованості ціннісного ставлення до створення сім'ї у студентської молоді $є$ потреби, інтереси за допомогою яких вони оцінюють значущість сім'ї для окремої особистості та суспільства загалом. Сформованість ціннісного ставлення до створення сім'ї $є$ основою формування готовності студентської молоді до сімейного життя, усвідомленого батьківства [4, 289].

Вітчизняна дослідниця Л. Канішевська визначає цінності сімейного життя як світоглядні уявленні та моральні настановлення, які засновані на традиційному розумінні інституту сім'ї, відносин людей в сім'ї, відповідальній шлюбній та сімейній поведінці індивіду, що забезпечують культурне та демографічне відтворення суспільства.

Особливостями цінностей сімейного життя як особистісних якостей людини є те, що вони соціальні за своєю природою, але індивідуальні за формами оволодіння та вираження; виконують функцію регуляторів поведінки, охоплюють усі сторони людського буття $[1,80]$.

Специфікою студентського контингенту в навчальних закладах аграрного профілю $є$ домінування сільської молоді, яка орієнтована на майбутню професійну діяльність в аграрному секторі економіки $[5,170]$.

Визначено критерії та показники сформованості ціннісного ставлення до створення сім'ї у студентів аграрних коледжів: когнітивний, емоційно-ціннісний, поведінково-діяльнісний.

Охарактеризовано критерії та відповідні показники сформованості ціннісного ставлення до створення сім’ї у студентів аграрних коледжів когнітивний (знання щодо сутності та функцій сім'ї; усвідомлення цінності сім'ї для окремої особистості та суспільства в цілому; усвідомлення важливості моральних цінностей (любові, дружби, вірності, взаємоповаги, взаєморозуміння) як основи сім'ї); емоційно-цінннісний (мотивація на створення сім'ї та виконання подружніх і батьківських обов'язків; здатність до емпатії; прагнення створювати сімейні відносини $і$ розвивати їх на основі моральних цінностей (любові, дружби, вірності, взаємоповаги, взаєморозуміння); поведінково-діяльнісний (здатністість до адекватного вибору поведінки в різних життєвих ситуаціях; наявність вміння спілкуватися 3 представниками протилежної статі; здатність до самовдосконалення себе як майбутнього сім'янина).

Під час дослідження було використано комплекс діагностичних методів і методик, а саме: анкетування, написання та аналіз студентських творів “Моя майбутня сім'я. Якою я іії бачу”, метод незакінчених речень, тестування (тест В. Бойка; тест “Мій запас міцності”), експертна оцінка, картка педагогічних спостережень, сюжетнорольова гра “Взаємні претензіі”, рольова гра “Інтерв'ю”, створення проблемних ситуацій, вправи "Мої плюси і мінуси”, “Яким мене бачать інші” (А. Яцеленко), “Чи готовий ти до сімейного життя " (Н. Оліфірович).

3 метою виявлення рівня знань студентів аграрних коледжів щодо функцій сім’і, їм було запропоновано запитання: “Які функції виконує сучасна сім'я?'

За даними анкетування 21,63 \% дівчат; 19,29 \% юнаків - студентів аграрних коледжів назвали більше трьох функцій сучасної сім'ї, серед яких: економічна, виховна, духовна, репродуктивна, організації дозвілля та відпочинку, комунікативна, побутово-господарська, емоційна тощо. Це свідчить про грунтовні знання щодо функцій сім'ї.

Слід зазначити, 29,81 \% дівчат; 30,46 \% юнаків - учасників експерименту мають достатні знання щодо сутності та функцій сім'ї.

Фрагментарні знання щодо функцій сім'ї мають $48,56 \%$ дівчат, та 50,25 \% юнаків - студентів аграрних коледжів.

На запитання анкети: “Що означає бути хорошим чоловіком? ” юнаки - студенти аграрних коледжів дали наступні відповіді: “добре 


\section{ВИВЧЕННЯ СТАНУ СФОРМОВАНОСТІ ЦІННІСНОГО СТАВЛЕННЯ ДО СТВОРЕННЯ СІМ'Ї У СТУДЕНТІВ АГРАРНИХ КОЛЕДЖІВ}

заробляти і забезпечувати свою сім'ю” (30,46 \%); “любити дружину, дітей, поважати родичів" $(22,84 \%)$; “не пиячити, не вживати наркотики” $(15,23 \%)$; “бути працелюбним” (12,18\%); “допомагати дружині, брати на себе важкі сімейні справи” (10,15 \%); “бути вірним” (9,14 \%).

На запитання анкети: “Що означає бути хорошою дружиною?” дівчата - студентки аграрних коледжів дали наступні відповіді: “любити чоловіка, дітей” (29,81 \%), “бути гарною господинею” (26,44 \%); “бути вірною” (21,63%), “завжди гарно виглядати, слідкувати за модою” $(9,62 \%)$; “виявляти поступливість, доброту, ніжність” (7,69 \%); “бути працелюбною” (4,81 \%).

Аналіз результатів дослідження за когнітивним критерієм свідчать, що 38,48 \% студентів аграрних коледжів виявили низький рівень сформованості ціннісного ставлення до створення сім' $\dddot{i} ; 37,03 \%$ студентів виявили середній рівень; високий рівень сформованості ціннісного ставлення до створення сім'ї за даним критерієм виявило 24,49\% студентів.

Проаналізуємо результати констатувального етапу експерименту щодо рівня сформованості ціннісного ставлення до створення сім'ї у студентів аграрних коледжів за емоційноціннісним критерієм (мотивація на створення сім'ї та виконання подружніх і батьківських обов'язків; здатність до емпатії; прагнення створювати сімейні відносини і розвивати їх на основі моральних цінностей (любові, дружби, вірності, взаємоповаги, взаєморозуміння). 3 метою вирішення цього завдання були використані наступні методи: анкетування, метод незакінчених речень.

Визначення рівня вихованості ціннісного ставлення до створення сім'ї у студентів аграрних коледжів за показником “мотивація на створення сім'ї та виконання подружніх і батьківських обов'язків" відбувалося за допомогою анкетування. Учасникам експерименту було запропоновано запитання : “Які мотиви, на Вашу думку, спонукають Вас до вступу у шлюб?” та було запропоновано з переліку мотивів обрати ті, що саме спонукають їх до вступу у шлюб. Оскільки учасники експерименту обирали кілька варіантів відповідей, сума отриманих виборів перевищувала 100 \%. Аналіз отриманих відповідей на зазначене запитання дозволяє стверджувати, що серед дівчат мотив “любов” займає перше місце (48,08 \%); на другому місці“бажання мати дітей, займатися їх вихованням" (45,67 \%); на третьому місці- “інтимно-сексуальні стосунки" $(43,27 \%)$, на четвертому місці "можливість вирішити свої житлові та матеріальні труднощі” (38,46 \%), на п’ятому місці “спільність поглядів та інтересів" (37,50 \%), на шостому місці - “страх залишитися самотньою” $(14,42 \%)$, на сьомому місці - “необхідність узаконити реальні подружні стосунки” (12,02 \%), восьме місце посідає мотив - “отримати соціальний статус одруженої особи” (9,62\%); дев'яте місце - “налагоджений побут” (7,22 \%) й десяте місце посідає мотив “вплив батьків, інших родичів" $(5,77 \%)$.

Аналіз отриманих даних на запитання: “Які мотиви, на Вашу думку, спонукають Вас до вступу у шлюб?” дозволяє констатувати, що серед юнаків перше місце посідає такий мотив, як “любов” (45,69 \%), на другому місці - “інтимносексуальні стосунки" (45,18 \%), на третьому місці - “налагоджений побут” (43,14 \%), четверте місце посідає мотив “спільність поглядів та інтересів" $(42,64 \%)$, п’яте місце - “бажання мати дітей, займатися їх вихованням” (40,61 \%), на шостому місці - “необхідність узаконити реальні подружні стосунки” (37,56 \%), восьме місце посідає мотив “можливість вирішити свої житлові та матеріальні проблеми" (35,53\%), дев'яте місце займає такий мотив, як “вплив батьків, інших родичів" $(12,69) \%$, останне місце займають такі мотиви, як “страх залишитися самотнім”, “отримати соціальний статус одруженої особи”.

Результати дослідження дозволяють констатувати, що 21,13\% студентів аграрних коледжів виявили високий рівень сформованості ціннісного ставлення до створення сім'ї за емоційно-ціннісним критерієм; середній рівень $31,64 \%$ студентів; низький рівень - 47,23\% студентів.

Вивчення рівня сформованості ціннісного ставлення до створення сім’ї у студентів аграрних коледжів за поведінково-діяльнісним критерієм (здатність до адекватного вибору поведінки в різних життєвих ситуаціях; вміння спілкуватися 3 представниками протилежної статі; здатність до самовдосконалення себе як майбутнього сім'янина) відбувалося за допомогою методів: тестування "Мій запас міцності” [2, 444 - 445], експертної оцінки, педагогічного спостереження, сюжетно-рольової гри “Взаємні претензії” [3, 153], створення проблемних ситуацій; вправ: "Мої плюси і мінуси”, “Яким мене бачать інші”.

Слід зазначити, що 24,39 \% студентів аграрних коледжів виявили високий рівень сформованості ціннісного ставлення до створення сім'ї за поведінково-діяльнісним критерієм; 32,22 \% студентів - середній рівень, 43,39 \% студентів низький рівень.

3 огляду на результати діагностики, відповідно 


\section{ВИВЧЕННЯ СТАНУ СФОРМОВАНОСТІ ЦІННІСНОГО СТАВЛЕННЯ ДО СТВОРЕННЯ СІМ'Ї У СТУДЕНТІВ АГРАРНИХ КОЛЕДЖІВ}

до означених критеріїв і показників було визначено три рівні сформованості ціннісного ставлення до створення сім'ї у студентів аграрних коледжів: високий, середній, низький.

Високий рівень. Студенти аграрних коледжів мають грунтовні знання щодо сутності та функцій сім’ і; усвідомлюють особистісну та суспільну цінність сім’ї у житті людини; важливість моральних цінностей (любові, дружби, вірності, взаємоповаги, взаєморозуміння) як основи сім' і; зорієнтовані на створення майбутньої сім'ї та виконання подружніх та батьківських обов'язків; виявляють співчуття, вболівання, чуйність, повагу до іншого; прагнення створювати сімейні відносини та розвивати їх на основі моральних цінностей (любові, дружби, вірності, взаємоповаги, взаєморозуміння); виявляють здатність прогнозувати свої дії та їх наслідки у конкретних життєвих ситуаціях; вміють спілкуватися з представниками протилежної статі на засадах партнерства, взаємодопомоги, взаємопідтримки; виявляють здатність до самовдосконалення себе як майбутнього сім'янина. Кількість таких студентів становила 23,34\%.

Середній рівень. Студенти аграрних коледжів мають достатні знання щодо сутності та функцій сім'ї; недостатньо усвідомлюють особистісну та суспільну цінність сім'ї у житті людини; важливість моральних цінностей (любові, дружби, вірності, взаємоповаги, взаєморозуміння) як основи сім'ї; недостатньо сформована мотивація на створення сім'ї та виконання подружніх та батьківських обов'язків; ситуативно виявляють співчуття та вболівання, чуйність, повагу до іншого; ситуативне прагнення створювати сімейні відносини та розвивати їх на основі моральних цінностей (любові, дружби, взаємоповаги, взаєморозуміння); не завжди здатні прогнозувати свої дії та їх наслідки у конкретних життєвих ситуаціях; мають труднощі у спілкуванні 3 представниками протилежної статі; ситуативно виявляють здатність до самовдосконалення себе як майбутнього сім'янина. Серед досліджених студентів аграрних коледжів таких було виявлено $33,63 \%$.

Низький рівень. Студенти мають фрагментарні знання щодо сутності та функцій сім’ї; не усвідомлюють особистісну та соціальну цінність сім'ї у житті людини; мають спотворені уявлення про сімейні стосунки; характеризуються відсутністю мотивації щодо створення сім'ї; виявляють нетерпимість, нестриманість, агресивність; не виявляють прагнення щодо створення сім'ї на основі моральних цінностей (любові, дружби, вірності, взаємоповаги, взаєморозуміння); не здатні прогнозувати свої дії та їх наслідки у конкретних життєвих ситуаціях; не вміють спілкуватися 3 представниками протилежної статі; не вважають за необхідне працювати над самовдосконаленням себе як майбутнього сім'янина. Кількість таких студентів $-43,03 \%$.

Висновки. Результати констатувального етапу дослідження засвідчили, що більшість студентів аграрних коледжів виявили низький рівень сформованості ціннісного ставлення до створення сім’ї - 43,03 \%; середній рівень сформованості ціннісного ставлення до створення сім 1 - 33,63\% студентів; високий рівень - 23,34 \% студенів аграрних коледжів.

Аналіз й узагальнення результатів констатувального етапу експерименту засвідчили необхідність теоретичного обгрунтування й експериментальної перевірки педагогічних умов формування ціннісного ставлення до створення сім'ї у студентів аграрних коледжів у позааудиторній діяльності.

\section{ЛITEРАТУРА}

1. Канішевська Л. В. Дослідження проблеми формування иінностей сімейного життя у старшокласників загальноосвітніх шкіл-інтернатів / Л. В. Канішевська. // Науковий вісник Начіонального університету біоресурсів і природокористування України. Серія "Педагогіка, психологія, філософія". / Редкол.: С. М. Ніколаєнко (відп. ред.) та ін. - К. : Міленіум, 2016. - Вип. 253. - C. 79-86.

2. Канішевська Л. В. Теоретико-методичні основи виховання соиіальної зрілості старшокласників загальноосвітніх икіл-інтернатів у позаурочній діяльності: дис. ...д-ра. пед. наук: спеи. 13. 00. 07 “Теорія і методика виховання" / Канішевська Любов Вікторівна. - Київ, 2011. - 512 c.

3. Сімейні цінності: навчально-методичний посібник до навчальної програми "Сімейні цінності" (70годин) [для 8-9x класів] / [О. В. Мельник, Т. В. Кравченко, Л. В. Канішевська, О. М. Пархоменко] - ІваноФранківськ: НАIP, 2014. - 252 c.

4. Шелест Н. А. Теоретичні аспекти проблеми готовності кураторів академічних груп до формування иіннісного ставлення до створення сім' $і$ у студентської молоді / Н. А. Шелест. // Науковий вісник Національного університету біоресурсів $i$ природокористування України. Серія "Педагогіка, психологія, філософія". / Редкол.: С. М. Ніколаєнко (відп. ред.) та ін. - К.: Міленіум, 2017. - Вип. 253. C. 294-299.

5. Школьна М. С. Особливості виховання соціальної зрілості у студентів аграрних коледжів у позааудиторній діяльності / М. С. Школьна. // Молодь і ринок. Щомісячний науково-педагогічний журнал. - 2017. - №7 (150). - C. 167-171. 


\section{REFERENCES}

1. Kanishevska, L. V. (2016). Doslidzhennia problemy formuvannia tsinnostei simeinoho zhyttia $u$ starshoklasnykiv zahalnoosvitnikh shkil-internativ [Research of problem for formation of values family life in senior pupils from general boarding schools]. Naukovyi visnyk Natsionalnoho universytetu bioresursiv i pryrodokorystuvannia Ukrainy. Seriia "Pedahohika, psykholohiia, filosofiia", vol. 253. pp. 7986 [in Ukrainian].

2. Kanishevska, L. V. (2011). Teoretyko--metodychni osnovy vykhovannia sotsialnoi zrilosti starshoklasnykiv zahalnoosvitnikh shkil-internativ u pozaurochnii diialnosti [Theoretical and methodical bases of education of social maturity of senior pupils of general educational boarding schools in extracurricular activities]. Doctor's thesis. Kyiv, 512 p. [in Ukrainian].

3. Melnyk, O. V., Kravchenko,T. V, Kanishevska, L. V. \& Parkhomenko, O. M. (2014). Simeini tsinnosti: navchalno-metodychnyi posibnyk do navchalnoi prohramy "Simeini tsinnosti" (70 hodyn) dlia 8-9kh klasiv [Family Values: academic and methodical textbook of an academic program "Family Values" (70 hours) for students in the eighth and ninth year]. Ivano-Frankivsk, 252 p. [in Ukrainian].

4. Shelest, N. A. (2017). Teoretychni aspekty problemy hotovnosti kuratoriv akademichnykh hrup do formuvannia tsinnisnoho stavlennia do stvorennia simi u studentskoi molodi [Theoretical aspects of the problem of the readiness of academic group facilitators to form students' value attitude to marry]. Naukovyi visnyk Natsionalnoho universytetu bioresursiv $i$ pryrodokorystuvannia Ukrainy. Seriia "Pedahohika, psykholohiia, filosofiia", vol. 259. pp. 294-299. [in Ukrainian].

5. Shkolna, M. S. (2017). Osoblyvosti vykhovannia sotsialnoi zrilosti u studentiv ahrarnykh koledzhiv u pozaaudytornii diialnos [The peculiarities of fostering of social maturity in students of agrarian colleges during the afterclass activities]. Molod $i$ rynok. Shchomisiachnyi naukovo-pedahohichnyi zhurnal, no. 7 (150), pp. 167-171. [in Ukrainian].

Стаття надійшла до редакції 29.02.2018

УДК 378.14.015.62

Антон Заболоцький, аспірант

Інституту інформаційних технологій $і$ засобів навчання НАПН України директор ичентра дистаниійного навчання Університет Економіки і права “КРОК”, м. Київ

\section{ЕКСПЕРИМЕНТАЛЬНА ПЕРЕВІРКА ЕФЕКТИВНОСТІ МЕТОДИКИ ВИКОРИСТАННЯ СИСТЕМИ ПІДТРИМКИ Е-LEARNING В РОЗВИТКУ IКТ- КОМПЕТЕНТНОСТЕЙ ПРАЦІВНИКІВ ЦДОУ}

У статті представлено аналіз поняття системи підтримки е-learning в університеті. Сформульовано моделі використання системи підтримки e-learning як засобу розвитку IКT-компетентностей працівників центтів дистаниійної освіти університетів. Сформульовані основні завдання, щзо повинна вирімувати система підтримки e-learning. Система підтримки e-learning у університеті була розроблена у контексті системного та інформаційного підходу відповідно до основних позицій щодо характерних властивостей, притаманних, з одного боку, педагогічним, з іншого боку, інформачійним системам.

Ключові слова: e-learning, дистанційна освіта, IКT-компетентность, IКT, вища школа.

Рис. 2. Табл. 2. Літ. 5.

Anton Zabolotskiy, Postgraduate Student Institute of Informational Technologies and Means of Studying National Academy of Pedagogical Sciences of Ukraine Director of the Center of Distance Studying University of Economics and Law "KROK”, Kyiv

\section{THE EXPERIMENTAL CHECKING OF EFFICIENCY OFTHE METHODOLOGY OF USING OF THE SUPPORT SYSTEM E-LEARNING FOR THE DEVELOPMENT OFTHE INFORMATIONALAND COMMUNICATIVE COMPETENCE OF THE EMPLOYEES}

The analysis of the development of university e-learning support system is presented in the article. The article presents the model of using the e-learning support system as a means of informational and communicative competence development of the employees of university of distance education center. The main tasks to be solved by the e-learning support system are formulated. The e-learning support system at the University was developed in the context of a systematic and informational approach in accordance with the main points regarding the characteristic features inherent, on the one hand, pedagogical, on the other hand, information systems. Under the e-learning support system, we understand the software product that allows the user to get information about the using of e-learning elements in the learning process, to solve the problem issues when working with e-learning elements. The article raises the problem of the university teachers' informational and 